\title{
Use of combined UV and chemical mutagenesis treatment of Aspergillus terreus D34 for hyper-production of cellulose-degrading enzymes and enzymatic hydrolysis of mild-alkali pretreated rice straw
}

\author{
Adepu K Kumar ${ }^{*}$, Bhumika S Parikh, Surendra P Singh and Deval Shah
}

\begin{abstract}
Background: Microbial production of cellulose-degrading enzymes could be significantly improved using traditional mutagenesis treatment. Development of high-titre cellulase producing mutants drastically reduces the costs involved in cellulase production and downstream processing in commercial-scale enzyme production. Here, we have evaluated the efficacy of different Aspergillus terreus D34 mutants for hyper-production of improved cellulase enzymes utilizing locally available lignocellulosic biomass residues as growth substrates in solid state fermentation conditions. Further, enzymatic hydrolysis of mild-alkali pre-treated rice straw was performed using the improved cellulases.

Results: A 4.9-fold higher $\beta$-glucosidase activity was obtained from ethyl methyl sulphonate (EMS) treated mutant strain (EMS2) when grown on mixed rice straw/sugarcane bagasse (RSBG) biomass growth substrate. Similarly with the EMS2 mutant and BG-grown culture extract a 1.1-fold higher xylanase activity was observed. Irrespective of the growth substrates and the mutant strains, the maximum cellulase (FPase, carboxymethyl cellulase, avicelase, $\beta$-glucosidase) and xylanase activities $\left(\mathrm{U} \mathrm{mL}^{-1}\right)$ were $2.34,39.8,2.46,19.9$ and 655 , respectively. Further, external supplementation of $20 \%$ bovine serum albumin (BSA), 3\% tween 80 and 20\% polyethylene glycol (PEG) 6000 to the crude enzyme extract increased the FPase activity nearly 4.0-, 2.8- and 2.2-fold. Addition of 0.05\% sodium benzoate marginally increased the stability of cellulase enzyme and retained more than $60 \%$ of the initial activity after $96 \mathrm{~h}$ incubation at $37^{\circ} \mathrm{C}$. While at $4^{\circ} \mathrm{C}$, no loss in enzyme activity was observed even after prolonged incubation period (up to 90 days). Further, maximum reducing sugars of $0.842 \mathrm{~g} \mathrm{~g}^{-1}$ at a rate of $0.25 \mathrm{mM} \mathrm{g}^{-1} \mathrm{~h}^{-1}$ at $10 \%$ biomass loading of mild-alkali pretreated rice straw was produced using the BG-grown culture extract of EMS2 mutant strain.

Conclusion: The extracellular protein production and corresponding cellulase activities of A. terreus D34 were significantly enhanced after combined UV and chemical mutagenesis treatments. In the present study, besides accelerating the rate of cellulase production, we have also demonstrated production of high reducing sugars by enzymatic saccharification of pretreated lignocellulosic biomass using hyper-produced cellulase enzymes. Due to high enzyme activity of the cellulase enzymes produced from the mutant strains, the volume of enzyme loadings in enzymatic hydrolysis could be reduced up to 7-fold. These studies clearly show the potential of the developed hyper-cellulase producing mutants in decreasing the overall process economics of cellulosic ethanol technology.
\end{abstract}

Keywords: A. terreus, Cellulases, Mutagenesis, Lignocellulosic biomass, Enzymatic hydrolysis

\footnotetext{
*Correspondence: kiranbio@gmail.com

Bioconversion Technology Division, Sardar Patel Renewable Energy

Research Institute, Post Box No. 2, Near BVM Engineering College, Vallabh

Vidyanagar 388 120, Gujarat, India
}

\section{垈 Springer}

(C) 2015 Kumar et al. This article is distributed under the terms of the Creative Commons Attribution 4.0 International License (http://creativecommons.org/licenses/by/4.0/), which permits unrestricted use, distribution, and reproduction in any medium, provided you give appropriate credit to the original author(s) and the source, provide a link to the Creative Commons license, and indicate if changes were made. 


\section{Background}

Lignocellulosic biomass is a renewable, abundant and inexpensive natural bioresource and is preferably used in the bioconversion processes for production of biofuels and other value added products. However, this bioconversion is quite challenging owing to the complex structural integrity of plant cell wall materials which is inherently designed to resist microbial degradation. One of the major structural components in all the lignocellulosic biomass materials is the cellulose and it could be converted into fuel ethanol with the help of cellulase enzymes. In nature, a number of bacteria and fungi are capable of producing cellulose-degrading enzymes which breakdown the complex polysaccharides into soluble oligomers and subsequently to monomeric sugars (Lynd et al. 2002). Among several hyper-cellulase producing fungal strains, filamentous fungi, Trichoderma sp. and Aspergillus sp. are considered as the major microbial sources for production of cellulase enzymes (Gusakov 2011). Trichoderma sp. is well known for commercial cellulase production but lacks in secreting sufficient $\beta$-glucosidase, while on the contrary, majority of the Aspergillus sp. produce high $\beta$-glucosidase enzymes.

Cellulases are a group of enzymes involved in the hydrolysis of cellulose and mainly consist of at least three major enzymes, namely exoglucanase (avicelase); endoglucanase (carboxymethyl cellulase, CMCase) and $\beta$-glucosidase (cellobiase). Synergistic action of these enzymes is vital for complete breakdown of cellulose into soluble sugars (Kim et al. 2014). Extensive basic and applied research on cellulases revealed their commercial significance and diverse industrial applicability, especially in bioethanol production (Bajpai 1999; Harman and Kubicek 1998; Uhlig 1998). However, the production economics of bioethanol is largely dependent on the cost of the cellulose-degrading enzymes (Reith et al. 2002). The enzyme production costs are tightly interlinked with the protein yield of cellulase in the fermentation broth as well as the enzyme activity. Therefore, continuous efforts towards the cost reduction of enzymes and increasing the overall protein production have been routed towards exploring hyperactive microbial strains, efficient fermentation techniques and cost-effective recovery systems (Laser et al. 2009). Use of different mutagenic agents for microbial strain improvement and fermentation processes was demonstrated by Parekh et al. (2000). Chand et al. (2005) reported generation of cellulase producing fungal mutants with more CMCase and filter paper cellulase production by simultaneous treatments with $N$-methyl- $N^{\prime}$-nitro- $N$-nitrosoguanidine (NTG), ethidium bromide and UV or NTG combined with ethidium bromide.
Enzymatic saccharification of the pre-treated lignocellulosic biomass depends on the hydrolytic efficiency of each individual cellulase enzyme component and their synergistic action as a multi-cellulase complex for breakdown of celluloses and hemicelluloses (Van Dyk and Pletchke 2012). Studies on enzymatic hydrolysis of lignocellulosic biomass have been focused on obtaining high yields of reducing sugars and optimization of the enzyme combinations which lead to an increase in the overall sugar yields. Since the major cost contribution $(\sim 20 \%)$ resides with these expensive enzymes, we have attempted to address this key issue in reducing the overall enzyme loadings in enzymatic hydrolysis by conventional mutagenesis of the cellulose-degrading Aspergillus terreus D34. Alongside, the enzyme activities were also evaluated in the presence of external additives. Very recently, we have reported optimization of microbial growth substrates and cost-effective production of cellulose-degrading enzymes from $A$. terreus D34 (Kumar and Parikh 2015). Here, we present combined UV and chemical mutagenesis treatment of the microbe towards generation of potential mutants for production of high efficient cellulose-degrading enzymes.

\section{Methods}

\section{Substrate, chemicals and media}

Rice straw (RS) and sugarcane bagasse (BG) biomasses were used as microbial growth substrates for enzyme production. BSA, $p$-nitrophenyl- $\beta$-D-glucopyranoside (PNPG), carboxymethyl-cellulose (CMC), avicel, cellobiose and 4-methylumbelliferyl- $\beta$-D-glucopyranoside (MUG), 4-methylumbelliferyl- $\beta$-D-cellobioside (MUC), PEG 6000, casein, tween 80 and sorbose were purchased from Sigma (St. Louis, MO, USA). Cheese whey was received from local milk dairy industry in Anand, Gujarat, India. All other reagents were obtained from commercial sources and were of analytical grade.

\section{Lignocellulosic biomass and microorganism}

The biomass residues (RS and BG) were procured from local agricultural fields near Anand district, Gujarat. Before use these were pre-washed extensively with water to remove loosely bound contaminants and then dried in sunlight for 3-4 days until the moisture content was $<5 \%$ $(\mathrm{w} / \mathrm{w})$. The dried biomass (es) were then cut into small sizes $(<5 \mathrm{~mm})$ using a hammer mill. The precut biomass residues were used directly in microbial growth media without any further processing. Isolation, morphological identification and microbial growth conditions of Aspergillus terreus D34 were recently described (Kumar and Parikh 2015; Narra et al. 2012). 


\section{Effect of UV and chemical mutagens}

Spore suspension from an overnight grown culture was prepared by serial dilution method. A $0.5-\mathrm{mL}$ culture with a $10^{6}$ dilution $\left(\sim 10^{5}-10^{6}\right.$ spores $\left.\mathrm{mL}^{-1}\right)$ was spread plated on a $0.5 \%$ CMC agar plate under sterile conditions. Each petri plate was then exposed to UV light (30 W lamp, $254 \mathrm{~nm}$ ) at a constant $10 \mathrm{~cm}$ distance for a treatment period of $15 \mathrm{~s}$ to $60 \mathrm{~min}$ at $28^{\circ} \mathrm{C}$. The $\mathrm{UV}$ treated petri plates were taken out at regular intervals (15-, 30-, 45-s, 1-, 5-, 15-, 30- and $60-\mathrm{min}$ ) and then incubated at $40^{\circ} \mathrm{C}$ for $72 \mathrm{~h}$ under dark conditions to avoid photo reactivation. The survivor microbial colonies $(<2 \%)$ after the UV treatment were then ranked and selected for cellulase production by zone of clearance method using Congo red dye. The selected UV mutant colonies were further screened for potential cellulase producing mutants in solid state cultivation.

Simultaneously, based on the FPase activity, the prominent UV mutant strains were further subjected to chemical mutagenesis treatment. For this, the culture suspension was prepared following similar method as described above. To $5 \mathrm{~mL}$ of cell suspension containing $\sim 10^{5}-10^{6} \mathrm{~mL}^{-1}$ viable cells, $5 \mathrm{~mL}$ of sterile ethyl methyl sulfonate (EMS) reagent (stock solution of $200 \mu \mathrm{g} \mathrm{mL}{ }^{-1}$ ) was added. The cells were withdrawn from the reaction mixture at regular intervals of 15-, 30-, 60-, 90-, 120- and 150-min. After the treatment period, to arrest the reaction samples were diluted immediately with sterile phosphate buffer $(50 \mathrm{mM}, \mathrm{pH} 7)$. The suspended samples were then centrifuged at 5,000 rpm for $10 \mathrm{~min}$ and cells were harvested and washed three times with sterile distilled water to remove traces of EMS reagent. The cells were serially diluted in phosphate buffer and plated for screening following the similar protocol as described above. EMS treated UV mutant microbial colonies were then ranked, selected from the plates and were tested for cellulase production as mentioned below.

\section{Cellulase production in solid state cultivation}

Seed inoculum was prepared in potato dextrose broth medium by transferring spore suspension containing $1.5 \times 10^{8}$ spores $\mathrm{mL}^{-1}$ from a 7 -days grown agar slant culture and then incubated in an orbital shaker with $180 \mathrm{rpm}$ at $45^{\circ} \mathrm{C}$ for $48 \mathrm{~h}$. Solid state cultivation was carried out separately in $500 \mathrm{~mL}$ Erlenmeyer flasks containing $5 \mathrm{~g}(\mathrm{w} / \mathrm{w})$ of rice straw, sugarcane bagasse and mixed (RSBG) growth substrate in the ratio of 75:25, 50:50 and $25: 75$, respectively, as a sole source of carbon for microbial growth as reported recently by us (Kumar and Parikh 2015).

\section{Determination of enzyme activities}

FPase activity was measured using filter paper (Whatman No. 1) as substrate at $37^{\circ} \mathrm{C}$ following the NREL protocol
(Ghose 1994). CMCase activity was assayed by incubating $0.5 \mathrm{~mL}$ of crude enzyme with $0.5 \mathrm{~mL}$ of $2 \%(\mathrm{w} / \mathrm{v}) \mathrm{CMC}$ in citrate buffer $\left(50 \mathrm{mM}, \mathrm{pH}\right.$ 5.0) for $30 \mathrm{~min}$ at $60^{\circ} \mathrm{C}$. Avicelase activity was measured similar to CMCase, except $2.5 \%$ avicel was used as substrate instead of CMC and incubated for $60 \mathrm{~min}$. The reducing sugars were determined by dinitrosalicylic acid (DNSA) method (Dashtban et al. 2010). $\beta$-Glucosidase assay was carried out by mixing $0.2 \mathrm{~mL}$ of culture supernatant and $0.2 \mathrm{~mL}$ of $0.01 \mathrm{M}$ PNPG and $1.6 \mathrm{~mL}$ of citrate buffer $(50 \mathrm{mM}, \mathrm{pH} 5.0)$. The reaction mixture was then incubated for $30 \mathrm{~min}$ at $60^{\circ} \mathrm{C}$. Reaction was stopped by addition of $4 \mathrm{~mL} \mathrm{NaOH}$-glycine buffer (0.2 M, pH 10.6) (Kubicek 1982). Xylanase activity was measured by incubating $0.5 \mathrm{~mL}$ of diluted enzyme with $0.5 \mathrm{~mL}$ of $1 \%(\mathrm{w} / \mathrm{v})$ birchwood xylan in citrate buffer $(50 \mathrm{mM}, \mathrm{pH} 5.0)$ for $30 \mathrm{~min}$ at $50^{\circ} \mathrm{C}$. Assays voiding either substrate or enzyme were also performed and used as control experiments to nullify the background effect on the enzyme activities. All the assay experiments were carried out in triplicates and mean values were calculated and presented here.

\section{SDS-PAGE analysis}

Non-denaturing SDS-PAGE was performed for zymogram analysis of CMCase, $\beta$-glucosidase, avicelase and xylanase. CMCase and xylanase activity was detected with Congo red dye staining method using an overlaying gel containing either $2 \%$ CMC or $2 \%$ birchwood xylan. In brief, a $10 \%$ separating gel was prepared and $30 \mu \mathrm{g}$ of crude cellulase enzyme protein from native and mutated samples was loaded. After electrophoresis, the gel was equilibrated with sodium citrate buffer $(50 \mathrm{mM}, \mathrm{pH}$ 5.0) for $30 \mathrm{~min}$ and was over layered on CMC or xylan containing polyacrylamide gel. This cassette was then enclosed in a plastic wrap and incubated at $60^{\circ} \mathrm{C}$ for $2 \mathrm{~h}$. Post incubation, the CMC or xylan containing gel was peeled off and was stained with $0.2 \%$ Congo red solution for $1 \mathrm{~h}$. To visualize the zone of clearance corresponding to the respective enzyme activity, de-staining was performed with $1 \mathrm{M} \mathrm{NaCl}$. For $\beta$-glucosidase and avicelase detection, the gels were incubated separately in $10 \mathrm{mM}$ MUG or $10 \mathrm{mM}$ MUC in citrate buffer (50 mM, pH 4.8) and visualized directly under UV-light. The developed fluorescent bands were then digitally captured using Syngene G-BOX gel documentation system.

Denaturing SDS-PAGE analysis was performed to evaluate the protein secretion levels into the extracellular culture extracts of wild-type and mutant strains. A $12 \%$ separating gel was prepared and $20 \mu \mathrm{L}$ of crude protein extract was loaded into each well. Electrophoresis was run at constant $140 \mathrm{~V}$ for $4 \mathrm{~h}$. After completion the gel was stained with coomassie brilliant blue R-250 (CBB R-250) dye and destained with methanol/acetic 
acid mixture until clear bands were visualized. The digital images were captured using the gel documentation system as mentioned above. Besides, a 4-20\% gradient gel was prepared following the instruction manual of BioRad to measure the molecular weight of the proteins. Prestained molecular markers were purchased from BioRad laboratories (Bio-Rad, USA). The molecular weight of protein subunits were measured by preparing standard secondary plots of log molecular weight verses retention factor $\left(R_{\mathrm{f}}\right)$ values.

\section{Effect of additives}

Different additives were tested to evaluate the effect on cellulase production and enzyme activity. Casein (0.5$1.5 \%, \mathrm{w} / \mathrm{w})$, sorbitol $(1.0-5.0 \%, \mathrm{w} / \mathrm{w})$ and cheese whey $(1.0-5.0 \%, w / w)$ were added separately into the growth medium and incubated for 7 days at $40^{\circ} \mathrm{C}$ in solid state cultivation. The conditions for microbial growth, enzyme production were kept similar as mentioned above, unless specified. To test the effect of additives on cellulase and hemicellulose activities, culture extracts $(1 \mathrm{~mL}$ each) were incubated separately with BSA (5.0-20\%), sodium benzoate $(0.005-0.1 \%)$, tween $80(0.5-5.0 \%)$ and PEG 6000 $(5-15 \%)$ for $1 \mathrm{~h}$ at room temperature and then assayed the corresponding enzyme activities following the protocol as described above. Control experiments voiding either enzyme or the additives were also performed to nullify background absorbance. The mean values from triplicate experiments were calculated and presented here.

\section{Effect of temperature on storage stability}

The crude concentrated cellulase enzyme samples from RS - and BG- grown extract were mixed with $0.05 \%(\mathrm{w} / \mathrm{v})$ sodium benzoate and incubated separately at $4^{\circ} \mathrm{C}$ for 90 days and at $37^{\circ} \mathrm{C}$ for 30 days, respectively. Control experiments were also performed simultaneously without sodium benzoate addition. The enzyme samples were withdrawn at regular intervals and FPase activity was measured following the protocol mentioned above.

\section{Mild-alkali pretreatment and enzymatic saccharification}

Mild-alkali pretreatment of the RS and BG using $\mathrm{NaOH}$ was performed following a recently described protocol (Kumar and Parikh 2015). Briefly, pre-treatment was performed by adding $200 \mathrm{~g}$ of dried lignocellulosic biomass to $4 \mathrm{~L}$ of $0.5 \%(\mathrm{w} / \mathrm{v}) \mathrm{NaOH}$ at a ratio of $1: 20$ (solid to liquid) and incubated at room temperature for $24 \mathrm{~h}$. The slurry was then neutralized with $1 \mathrm{~N} \mathrm{HCl}$ and filtered to separate solid biomass residues. The solid residue was then washed thoroughly with distilled water until the glucose concentration was below $0.1 \mathrm{mg} \mathrm{mL}^{-1}$ (measured by HPLC) in the flow through and the residual solid biomass was dried at $60^{\circ} \mathrm{C}$ till constant weight.
Enzymatic hydrolysis was carried out separately at 10, 15 and $20 \%$ solids loading of the pretreated biomass residue at $45^{\circ} \mathrm{C}$ for $48 \mathrm{~h}$ in $50 \mathrm{~mL}$ screw capped bottles with a total reaction volume of $10 \mathrm{~mL}$ containing $9 \mathrm{FPU} \mathrm{g}^{-1}$ biomass of crude cellulase enzymes obtained from RSand BG-grown culture extracts. Saccharification was performed in a temperature-controlled incubator with a fixed angle free falling horizontal reactor at $10 \mathrm{rpm}$ (Kumar and Parikh 2015). Control experiments were also performed without substrate and enzyme. After enzymatic hydrolysis, the liquid content was separated from the residual biomass by filtration using glass fiber filter membranes. Reducing sugars were analyzed by DNSA method as described above.

\section{Analytical methods}

Compositional analysis of untreated and pre-treated lignocellulosic biomass residues was determined following the method described by Goering and Van Soest (1970). As there was no free flowing water in SSF, after microbial growth the contents were mixed with $40 \mathrm{~mL}$ of citrate buffer ( $50 \mathrm{mM}, \mathrm{pH} 5.0)$ and then incubated in an orbital shaker for $60 \mathrm{~min}$ at $200 \mathrm{rpm}$ such that the loosely bound proteins will be solubilized into the extracellular culture extract. The so obtained culture extracts were used for protein estimation. Protein concentration was determined using BSA as standard following the method described by Bradford (1976), while the protein content present in fresh biomass was estimated using total \% nitrogen following AOAC (1990) Official method. Besides, SDS-PAGE was also run to test the protein production profile from the biomass-grown culture extracts of wild-type and mutants. All the assay experiments were carried out in triplicate and the mean values are given. Statistical analysis was performed using ANOVA software and all the data presented in this study were the mean of three or more experiments with a variation within $10 \%$.

\section{Results and discussion}

UV and chemical mutagenesis of $A$. terreus

Recently, we have reported the growth of A. terreus D34 on different lignocellulosic biomass residues and biochemical studies of crude cellulose-degrading enzymes (Kumar and Parikh 2015; Narra et al. 2012). Significant improvement in extracellular protein production and cellulase activities was observed when the filamentous fungus was subjected to conventional mutagenesis by UV and chemical treatments. Among the generated UV mutant strains, two mutants viz. UV1 and UV2 showed maximum zone of clearance on CMC agar plate with a cellulolytic index of 34 and $36 \mathrm{~mm}$ (data not shown) and were selected for strain improvement studies (Additional 
file 1: Table S1). Unlike wild type (WT), the mutants were non-sporulating after UV irradiation (Additional file 1: Figure S1). In general, non-sporulating filamentous fungi are preferred over sporulating microbes, because of severe clogging effect on the separating membranes. Besides a cost-intensive process, it is considered as one of the major constraints in downstream processing of industrial enzymes (Pandey et al. 1999). The molecular reason behind such drastic morphological and genetic metamorphism is not clearly known, except where UV radiation induces formation of pyrimidine dimers in the genomic DNA. Ikehata and Ono (2011) reported different types of mechanisms of UV mutagenesis and their effect on DNA damage and protein synthesis process. Moreover, chemical mutagenesis treatment of the developed UV mutants further improved cellulase production and activity as shown in later sections.

\section{Cellulase production in different growth substrates}

Since use of purified cellulose or its chemically synthesized products as a growth substrate is uneconomical in pilot scale microbial cellulase production; cheap, abundantly available and region-specific natural biorenewable lignocellulosic biomass substrates viz. rice straw (RS) and sugarcane bagasse (BG) for microbial growth and cellulase production are preferred (Kumar and Parikh 2015; Pandey et al. 1999; Bajaj et al. 2014; Rocha et al. 2013). Very recently, El-Ghonemy et al. (2014) and Palaniyandi et al. (2014) used rice straw for hyper-production of cellulases from mutant strains of $A$. oryzae NRRL 3484 and Hypocrea koningii RSC1 in solid state fermentation. In this study we observed that during growth on RS biomass, maximum extracellular protein content reached up to 72.2 and $66.9 \mathrm{~g} \mathrm{~L}^{-1}$ with EMS2 and UV2 mutants, while with $\mathrm{BG}$ biomass, the protein production was marginally elevated from 31.2 to $57.9 \mathrm{~g} \mathrm{~L}^{-1}$ (Table 1). The reduced protein production levels in BG-grown culture extract as compared to RS-grown culture extract could be due to high lignin content in BG biomass which has high recalcitrance towards microbial breakdown. This was further confirmed by our mixed (RSBG) growth substrate results, where gradual decrease in the supplementation of BG biomass (75-25\%) to the growth media increased the extracellular protein production. Besides, the crude protein content of the RS and BG biomass residues were found to be $1.5 \pm 0.1 \mathrm{~g} \mathrm{~g}^{-1}$ of biomass, which contributes nearly $6.2-10 \%$ of the overall extracellular protein, when WT protein content was compared, whereas with EMS2 mutant, the protein contribution from the biomass residues was significantly lower, i.e. $2.0 \%$ from RS biomass and $5.2 \%$ from BG biomass. The high extracellular protein production levels from the $A$. terreus mutants were closely comparable with majority of the industrial fungal cellulase producers. For example, it is reported that $T$. reesei, the most well-known commercial cellulase producing strain, secretes nearly $40 \mathrm{~g} \mathrm{~L}^{-1}$ and reputedly up to $100 \mathrm{~g} \mathrm{~L}^{-1}$ of extracellular cellulases (Gusakov 2011).

\section{Enzyme activities from wild type and mutants}

CMCase, avicelase, FPase and $\beta$-glucosidase activities in the UV and EMS mutants were nearly two- to fivefold higher than the WT cells in all the test growth substrates (Table 2). Irrespective of mutants and biomass growth substrates, highest enzyme activities obtained were: $39.7 \mathrm{U} \mathrm{mL}^{-1}$ CMCase in EMS2 and BG biomass; $2.46 \mathrm{U} \mathrm{mL}^{-1}$ avicelase in UV1 and BG biomass; 2.34 $\mathrm{U} \mathrm{mL}^{-1}$ FPase in EMS1 and RS25:BG75 biomass; $19.9 \mathrm{U} \mathrm{mL}^{-1} \beta$-glucosidase in EMS2 and RS75:BG25 biomass, respectively. The detailed enzyme activities from the wild-type and mutant strains are given in Table 2. Recent findings also showed that in $A$. niger mutated strain, a twofold higher CMCase activity was observed after UV

Table 1 Protein production profile from wild-type and mutant strains grown on rice straw and sugarcane bagasse biomass substrates

\begin{tabular}{|c|c|c|c|c|c|c|c|c|c|c|}
\hline \multirow[t]{3}{*}{ Strain } & \multicolumn{10}{|c|}{ Growth substrate } \\
\hline & \multicolumn{2}{|l|}{ Rice straw } & \multicolumn{2}{|c|}{ Sugarcane bagasse } & \multicolumn{2}{|l|}{ RS75:BG25 } & \multicolumn{2}{|c|}{ RS50:BG50 } & \multicolumn{2}{|c|}{ RS25:BG75 } \\
\hline & $\begin{array}{l}\text { Protein } \\
\left(\mathrm{g} \mathrm{L}^{-1}\right)\end{array}$ & $\begin{array}{l}\text { Fold } \\
\text { increase }\end{array}$ & $\begin{array}{l}\text { Protein } \\
\left(\mathrm{g} \mathrm{L}^{-1}\right)\end{array}$ & $\begin{array}{l}\text { Fold } \\
\text { increase }\end{array}$ & $\begin{array}{l}\text { Protein } \\
\left(\mathrm{g} \mathrm{L}^{-1}\right)\end{array}$ & $\begin{array}{l}\text { Fold } \\
\text { increase }\end{array}$ & $\begin{array}{l}\text { Protein } \\
\left(\mathrm{g} \mathrm{L}^{-1}\right)\end{array}$ & $\begin{array}{l}\text { Fold } \\
\text { increase }\end{array}$ & $\begin{array}{l}\text { Protein } \\
\left(\mathrm{g} \mathrm{L}^{-1}\right)\end{array}$ & $\begin{array}{l}\text { Fold } \\
\text { increase }\end{array}$ \\
\hline WT & $24.2 \pm 1.8$ & 1 & $14.6 \pm 4.1$ & 1 & $31.2 \pm 4.5$ & 1 & $25.2 \pm 4.6$ & 1 & $28.6 \pm 4.3$ & 1 \\
\hline UV1 & $43.2 \pm 2.5$ & 1.78 & $29.6 \pm 5.2$ & 2.02 & $54.2 \pm 3.6$ & 1.73 & $42.2 \pm 4.2$ & 1.67 & $35.6 \pm 3.2$ & 1.24 \\
\hline UV2 & $66.9 \pm 2.8$ & 2.76 & $24.9 \pm 5.0$ & 1.70 & $57.9 \pm 3.2$ & 1.85 & $25.6 \pm 3.8$ & 1.01 & $32.6 \pm 2.8$ & 1.13 \\
\hline EMS1 & $53.6 \pm 1.5$ & 2.21 & $26.6 \pm 4.3$ & 1.82 & $53.2 \pm 2.8$ & 1.70 & $35.9 \pm 3.0$ & 1.42 & $38.9 \pm 2.5$ & 1.36 \\
\hline EMS2 & $72.2 \pm 3.1$ & 2.98 & $26.6 \pm 3.2$ & 1.82 & $52.9 \pm 2.9$ & 1.69 & $42.9 \pm 3.1$ & 1.70 & $34.6 \pm 3.5$ & 1.20 \\
\hline
\end{tabular}

Values are the average of three repetitions; standard deviations did not exceed $<10 \%$ of the mean.

$R S$ rice straw, $B G$ sugarcane bagasse, WT wild type, UV UV-mutants, EMS chemical mutants. 
Table 2 Enzyme activities from the wild-type and mutant strains grown on RS, BG and mixed RSBG growth substrates

\begin{tabular}{|c|c|c|c|c|c|c|}
\hline \multirow[t]{2}{*}{ Strain } & \multirow[t]{2}{*}{ Growth substrate } & \multicolumn{5}{|c|}{ Enzyme activity $\left(\mathrm{U} \mathrm{mL}^{-1}\right)$} \\
\hline & & FPase & Avicelase & CMCase & $\beta$-Glucosidase & Xylanase \\
\hline WT & Rice straw & $0.61 \pm 0.05$ & $0.97 \pm 0.03$ & $15.31 \pm 1.2$ & $4.87 \pm 0.25$ & $267 \pm 7.0$ \\
\hline UV1 & & $1.41 \pm 0.09$ & $3.72 \pm 0.05$ & $36.83 \pm 1.7$ & $8.50 \pm 0.43$ & $204 \pm 6.7$ \\
\hline UV2 & & $1.34 \pm 0.08$ & $1.51 \pm 0.03$ & $38.16 \pm 2.0$ & $13.5 \pm 0.62$ & $235 \pm 7.6$ \\
\hline EMS1 & & $1.67 \pm 0.1$ & $1.59 \pm 0.05$ & $35.47 \pm 1.1$ & $11.37 \pm 0.56$ & $242 \pm 6.1$ \\
\hline EMS2 & & $2.07 \pm 0.06$ & $2.31 \pm 0.03$ & $33.11 \pm 1.3$ & $5.12 \pm 0.25$ & $266 \pm 7.3$ \\
\hline WT & Sugarcane bagasse & $0.93 \pm 0.05$ & $0.47 \pm 0.06$ & $17.89 \pm 0.9$ & $4.68 \pm 0.01$ & $583 \pm 7.7$ \\
\hline UV1 & & $1.27 \pm 0.06$ & $1.00 \pm 0.11$ & $35.84 \pm 1.4$ & $6.87 \pm 0.56$ & $552 \pm 8.1$ \\
\hline UV2 & & $1.70 \pm 0.05$ & $0.42 \pm 0.1$ & $31.59 \pm 1.2$ & $8.12 \pm 0.31$ & $616 \pm 8.8$ \\
\hline EMS1 & & $1.74 \pm 0.07$ & $0.95 \pm 0.1$ & $38.00 \pm 1.6$ & $9.43 \pm 0.75$ & $646 \pm 10$ \\
\hline EMS2 & & $1.69 \pm 0.06$ & $0.95 \pm 0.11$ & $39.8 \pm 1.7$ & $9.12 \pm 1.0$ & $656 \pm 9.8$ \\
\hline WT & RS75:BG25 & $0.52 \pm 0.03$ & $0.50 \pm 0.02$ & $6.21 \pm 0.6$ & $4.0 \pm 0.18$ & $138 \pm 6.2$ \\
\hline UV1 & & $1.56 \pm 0.08$ & $0.67 \pm 0.11$ & $28.95 \pm 1.5$ & $15.5 \pm 0.43$ & $215 \pm 6.6$ \\
\hline UV2 & & $1.41 \pm 0.05$ & $0.20 \pm 0.006$ & $26.57 \pm 1.3$ & $16.0 \pm 0.68$ & $214 \pm 6.9$ \\
\hline EMS1 & & $1.35 \pm 0.06$ & $0.18 \pm 0.006$ & $21.03 \pm 1.1$ & $12.5 \pm 0.81$ & $228 \pm 7.5$ \\
\hline EMS2 & & $2.09 \pm 0.11$ & $0.30 \pm 0.01$ & $30.42 \pm 1.3$ & $19.9 \pm 1.12$ & $252 \pm 6.5$ \\
\hline WT & RS50:BG50 & $0.71 \pm 0.04$ & $0.45 \pm 0.06$ & $7.99 \pm 0.8$ & $4.56 \pm 0.12$ & $273 \pm 7.8$ \\
\hline UV1 & & $1.46 \pm 0.05$ & $0.35 \pm 0.06$ & $33.53 \pm 1.5$ & $7.93 \pm 0.56$ & $260 \pm 7.0$ \\
\hline UV2 & & $1.60 \pm 0.03$ & $0.16 \pm 0.06$ & $24.75 \pm 1.2$ & $10.5 \pm 1.12$ & $222 \pm 6.4$ \\
\hline EMS1 & & $1.64 \pm 0.02$ & $0.34 \pm 0.01$ & $25.54 \pm 1.1$ & $10.0 \pm 1.0$ & $240 \pm 7.2$ \\
\hline EMS2 & & $2.01 \pm 0.07$ & $0.48 \pm 0.06$ & $32.20 \pm 1.4$ & $12.37 \pm 1.12$ & $268 \pm 6.3$ \\
\hline WT & RS25:BG75 & $0.67 \pm 0.02$ & $0.30 \pm 0.01$ & $9.15 \pm 0.8$ & $3.93 \pm 0.06$ & $292 \pm 6.8$ \\
\hline UV1 & & $1.45 \pm 0.03$ & $0.27 \pm 0.01$ & $27.19 \pm 1.1$ & $6.06 \pm 0.25$ & $185 \pm 6.1$ \\
\hline UV2 & & $1.95 \pm 0.05$ & $0.52 \pm 0.06$ & $25.87 \pm 1.3$ & $7.93 \pm 1.31$ & $320 \pm 7.5$ \\
\hline EMS1 & & $2.34 \pm 0.06$ & $0.67 \pm 0.08$ & $30.92 \pm 1.2$ & $7.43 \pm 1.06$ & $285 \pm 8.2$ \\
\hline EMS2 & & $1.91 \pm 0.05$ & $0.62 \pm 0.01$ & $21.52 \pm 1.1$ & $7.25 \pm 0.81$ & $324 \pm 8.0$ \\
\hline
\end{tabular}

Values are the average of three repetitions; standard deviations did not exceed $<10 \%$ of the mean.

treatment (Irfan et al. 2011). Similarly El-Ghonemy et al. (2014) reported that UV radiation followed by chemical mutagenesis of $A$. oryzae increased the FPase activity by fourfold. Shafique et al. (2011) also reported that to mutagenesis with UV and EMS of T. viride FCBP-142 increased cellulase activities by twofold. Comparing the xylanase activities within the group of the tested growth substrates, no significant increase was observed with the mutants. But, when compared with RS- and BG-grown culture extracts, a twofold higher xylanase activity was obtained with the BG biomass. These results are in line with our recent findings on wild-type enzyme activities, compared to RS more number of xylanases were produced in the BG biomass, thus higher enzyme activity (Kumar and Parikh 2015). The plausible reason attributed to higher xylanase activity in BG-grown extracts might be due to the high content of hemicelluloses in BG biomass, which could have induced more number of xylanases into the extracellular medium for effective breakdown and utilization of the hemicellulose fraction. Since CMCase and $\beta$-glucosidase are expressed by individual genes, the variations observed in enzyme activities after two mutagenic treatments were mostly due to the gene level modifications, besides the level of treatment time. As the mutation occurs at the gene level, the translation process for secretion of extracellular proteins might have been induced by the UV treatment. It also suggests that the mutagenic treatments triggered the induction of cellulase transcription regulation pathway for hyper-secretion of each enzyme variant in effective utilization of lignocellulosic biomass for microbial growth. Dhawan et al. (2003) reported that fungi treated with mutagens at sublethal concentrations increase the secretory enzyme production. In most of the microbial mutagenesis studies, UV treatment was generally followed by chemical treatment to avoid back mutation (Chand et al. 2005). Based on the enzyme activities, protein concentrations and SDS-PAGE analysis from the sub-cultured UV and EMS mutants from 30 different experiments in 8 months period clearly showed no difference in either enzyme activity or extracellular proteins production levels (data not shown). This strongly indicates that the generated mutagens were highly stable. 


\section{Zymogram analysis of different cellulase enzymes}

Recently we have reported detailed characterization and identification of WT enzyme variant from culture extracts of RS and BG growth substrates (Kumar and Parikh 2015). Similarly, the crude culture extracts from the UV and chemical mutants (UV1, UV2, EMS1 and EMS2) also showed no major difference in cellulase and xylanase variants (indicated by arrows) when compared to the wild-type culture extracts (Additional file 1: Figure S2). Since no difference in the enzyme variants from the mutants were observed, detailed description of each individual enzyme variant is not described here, and further suggested to refer our recent report (Kumar and Parikh 2015). Besides, it is highly intriguing to observe that after UV and EMS treatment there was a significant increase in the extracellular protein production levels (Table 1) and is accompanied with high enzyme activities (Table 2). These results were strongly supported by SDS-PAGE analysis. A correlation was made between the band pattern and the protein production profile. From PAGE analysis, we conclude that mutation induced high protein secretion that was evident from thick intense protein bands at equal loading volumes of extracellular proteins from each culture broth. Since the RS culture broth was highly colored (Additional file 1: Figure S3), several appropriate dilutions were made to nullify the smearing effect and to visualize the protein bands. At such high dilutions, the protein bands from the wild type were not clearly visible. Decreasing the dilution increased the smearing effect in the mutants (Fig. 1). High intense protein bands were observed with the mutant strain culture extracts from both the growth biomass residues (lanes $2-5$ in Fig. 1a, b) as compared to the wild-type culture extract (lane 1 in Fig. 1a, b). Critical examination of protein bands in BG-grown culture extract, a significant induction of all proteins was observed and was determined by protein estimation too. Whereas in RS-grown culture extracts, the major contribution in protein concentration was associated with a high intense protein band of approximate molecular weight $98 \mathrm{kDa}$. The molecular weights of the protein subunits were calculated using the standard plots drawn between log molecular weight of markers verses the mobility $\left(R_{\mathrm{f}}\right)$ values (Additional file 1: Figure $\mathrm{S} 4)$. These results strongly support the quantitative analysis (protein estimation) of the extracellular proteins performed by colorimetric method. Thus, it may be inferred that the high enzyme activities were mainly due to more secretion of the respective cellulase and xylanase protein components into the extracellular culture medium rather than the induction and expression of additional cellulose degrading enzymes, and were also evident from the corresponding specific activities of each enzyme variant (Additional file 1: Figure S5).

\section{Effect of additives on cellulases production}

Addition of 20\% BSA to the crude RS-grown culture extract increased the FPase activity by fourfold, followed by BG-grown culture extract where 1.6-fold increase was observed with $10 \%$ BSA (Fig. 2). The results suggest that BSA acts as a good stabilizing agent. Moreover, a recent study on effect of BSA on cellulase activity showed that presence of BSA decreases the adsorption of cellulase enzyme to the filter paper and increased the conversion rate of cellulose (Wang et al. 2013). To explore the promising strategies in reducing the enzyme requirements during the hydrolysis of cellulose, we further expanded our investigation towards other additives. Similarly, a 2.8fold increase the FPase activity was obtained with addition of 2-3\% tween 80 in RS- and RSBG-grown culture extracts, respectively (Fig. 3). Kim et al. (2006) reported that the substrate accessibility and hydrolytic activity of CBH I enzyme were increased by addition of tween 80 in $T$. viride by decreasing the absorption of enzyme on to cellulose.

Additionally, supplementation of PEG 6000 to the crude enzyme mixture increased the cellulase activity linearly with the concentration of PEG. At 20\% PEG 6000 , the cellulase activity was maximum with a 2.2 -fold increase with the RSBG-grown culture extract, and followed by BG- and RS-grown culture extracts (Fig. 4). Recently, Zong et al. (2015) reported that addition of PEG to the crude cellulase enzymes would be beneficial to reduce the enzyme load during enzymatic hydrolysis and suggested a possible mechanism of interaction of PEG with the cellulase enzymes. The hydrophobic effects and the hydrogen bonds formed between PEG and the key amino acids contributed to the enhancement of cellulase activity. Similarly, incubation with $0.05 \%$ sodium benzoate marginally increased the stability of cellulase enzyme and retained more than $60 \%$ of the residual enzyme activity after $96 \mathrm{~h}$ incubation at $37^{\circ} \mathrm{C}$, whereas at $4^{\circ} \mathrm{C}$, no loss in enzyme activity was observed even after prolonged incubation period (90 days) (Fig. 5). Supplementation of $0.5 \%$ casein enhanced the total cellulase activity by 1.5 -fold, while sorbose and cheese whey were found to be detrimental for cellulase and xylanase production (Additional file 1: Table S2). Recently, Kosalkova et al. (2012) reported that casein or its biopolymers significantly increased the secretion of extracellular proteins up to 40 - to 80 -fold in A. awamori. Similarly Kawamori et al. (1986) also tested L-sorbose for induction and production of CMCases in T. reesi, where avicel and glucose supplemented with $0.3 \%$ sorbose enhanced the CMCase activity by twofold. Cheese whey is generally used as a low-cost nitrogen source in large-scale enzyme productions from bacteria and fungi. However, our experiments did not show any positive effect on secretion of 


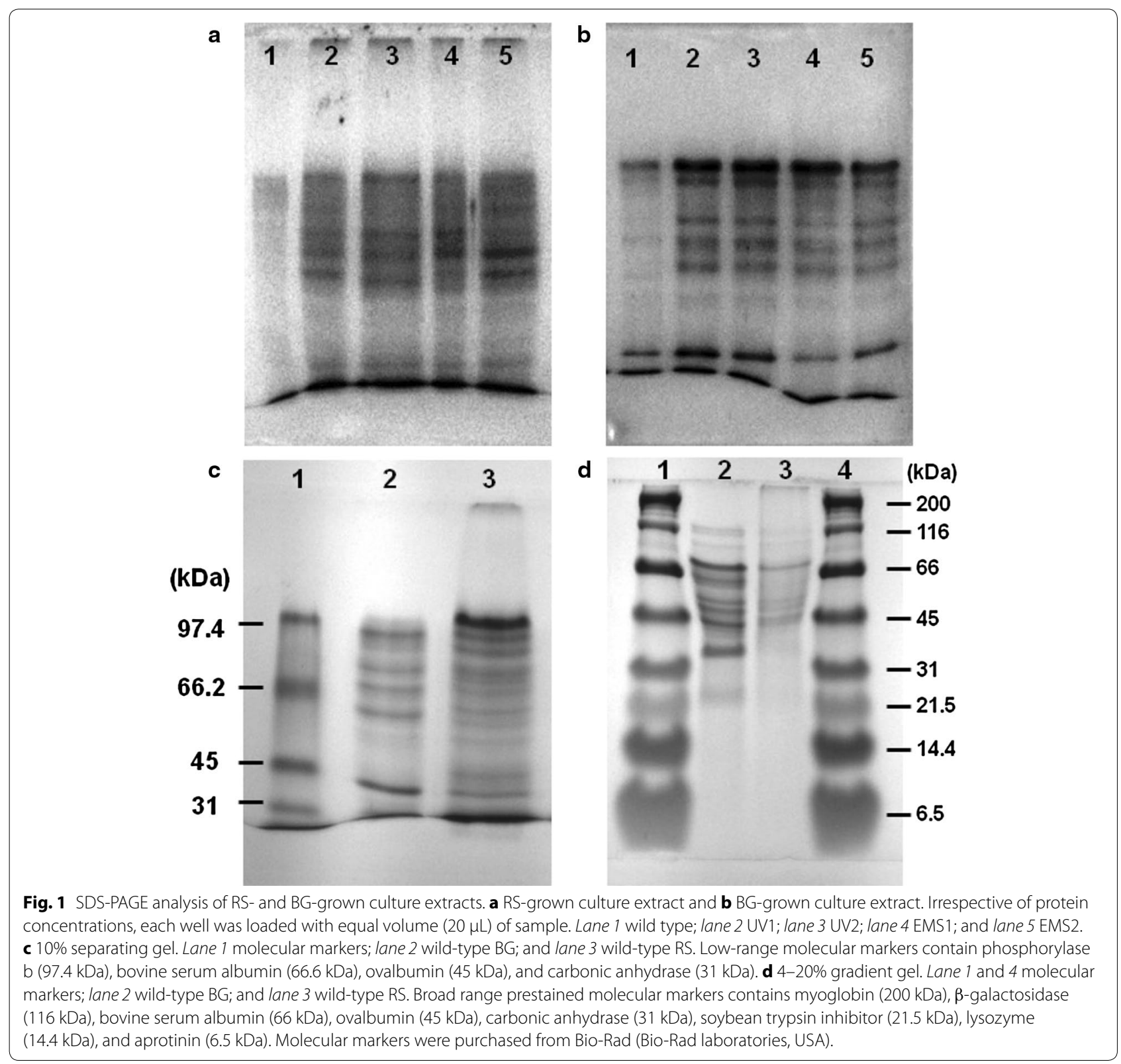

cellulases, rather decreased the production of extracellular enzymes.

\section{Enzymatic saccharification of rice straw}

Enzymatic hydrolysis of mild alkali pretreated rice straw biomass produced maximum reducing sugars of $0.842 \mathrm{~g} \mathrm{~g}^{-1}$ at $10 \%$ solids loading and $9 \mathrm{FPU} \mathrm{g}^{-1}$ enzyme after $48 \mathrm{~h}$ of incubation and a saccharification efficiency of $95 \pm 0.2 \%$ was obtained with the cellulase enzyme secreted by the EMS2 mutant strain grown on BG-grown culture extract. However, marginally lower saccharification yields were obtained with UV1, UV2 and EMS1 mutant enzymes. The saccharification yields with the RS- and BG-grown culture extracts were within $83-89 \%$ and $87-94 \%$, respectively. But, the required volume of cellulase enzyme to obtain 9 FPU significantly varied among these strains. A threefold less enzyme mixture is required for saccharification studies in case of EMS2, whereas from other mutant strains the crude cellulase enzyme needed was two- to threefold higher. Since, the cellulase enzymes contribute nearly 20-30\% of the total cost (Lynd et al. 2008), this reduction in enzyme volumes plays a significant role during the overall cost estimations of the production of fermentable sugars from lignocellulosic biomass residues. Moreover, the rate of production of reducing sugars was found to 


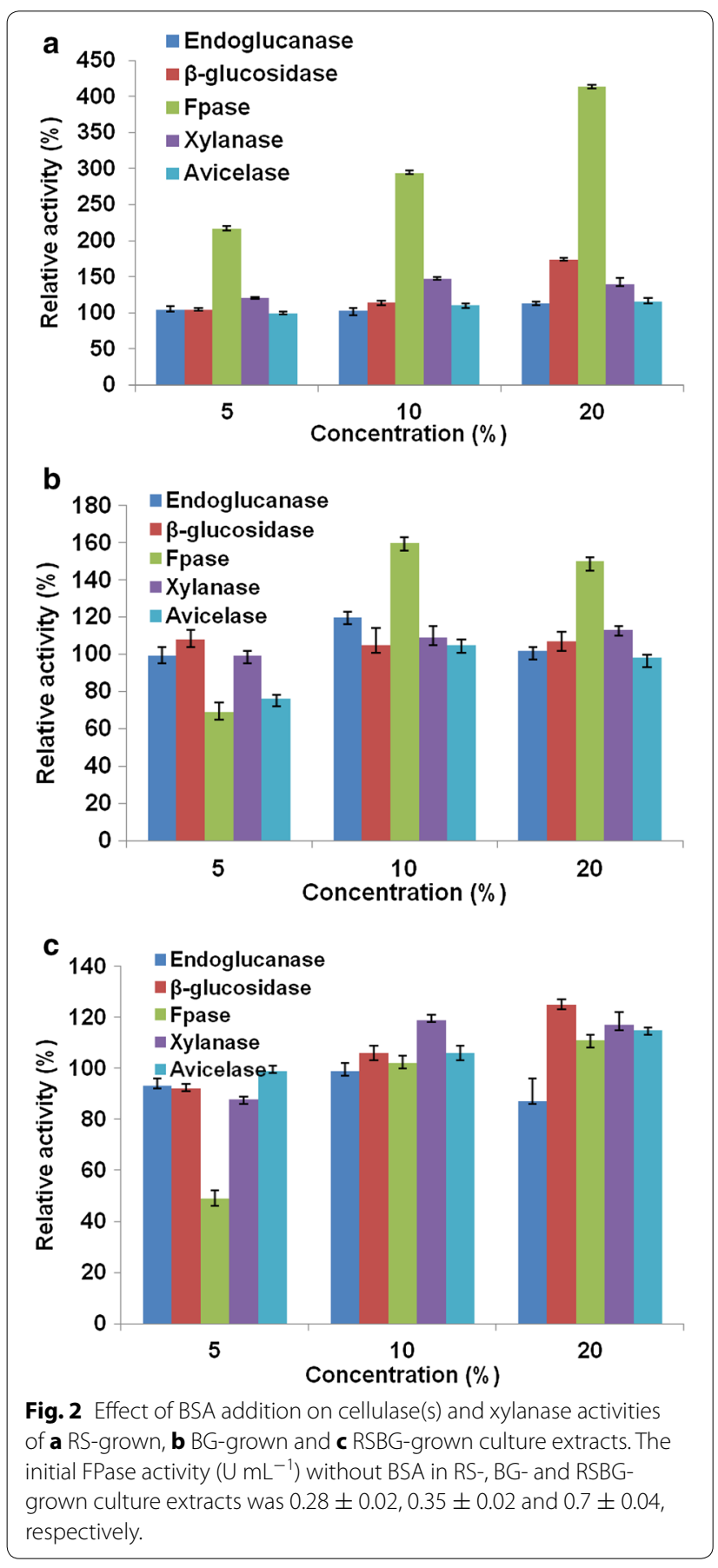

be increased with the EMS mutants $\left(0.25 \mathrm{mM} \mathrm{g}^{-1} \mathrm{~h}^{-1}\right)$ compared to the wild-type $\left(0.14 \mathrm{mM} \mathrm{g}^{-1} \mathrm{~h}^{-1}\right)$ (Fig. 6). The results showed that the bioconversion process was accelerated when improved enzymes from the mutants were used and more importantly decreased the incubation period up to twofold to obtain the same amount of fermentable sugars. These data strongly suggest a potential reduction in the overall cost of the bioconversion
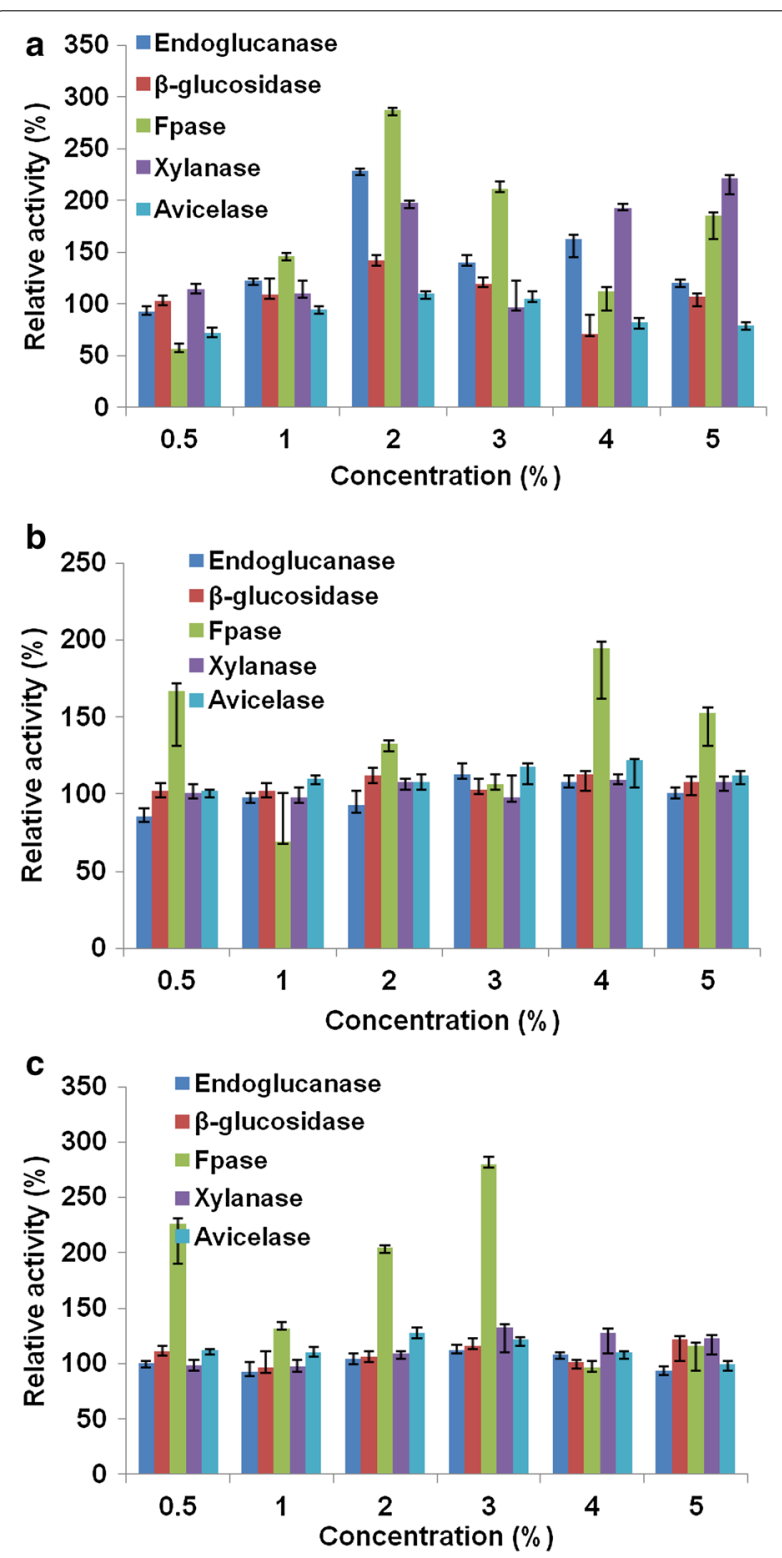

Fig. 3 Effect of tween 80 addition on cellulase(s) and xylanase activities from a RS-grown, b BG-grown and c RSBG-grown culture extracts. The initial FPase activity $\left(\mathrm{U} \mathrm{mL}^{-1}\right)$ without tween 80 in RS-, BG- and RSBG-grown culture extracts were $0.28 \pm 0.02,0.35 \pm 0.02$ and $0.7 \pm 0.04$, respectively.

process for production of reducing sugars from lignocellulosic biomass residues.

\section{Conclusion}

Strain improvement of A. terreus D34 by physical mutation (UV irradiation) followed by chemical mutation (EMS) generated potential mutant strains capable of secreting high levels of cellulase proteins with enhanced enzyme activities. After UV irradiation $A$. terreus mutants 


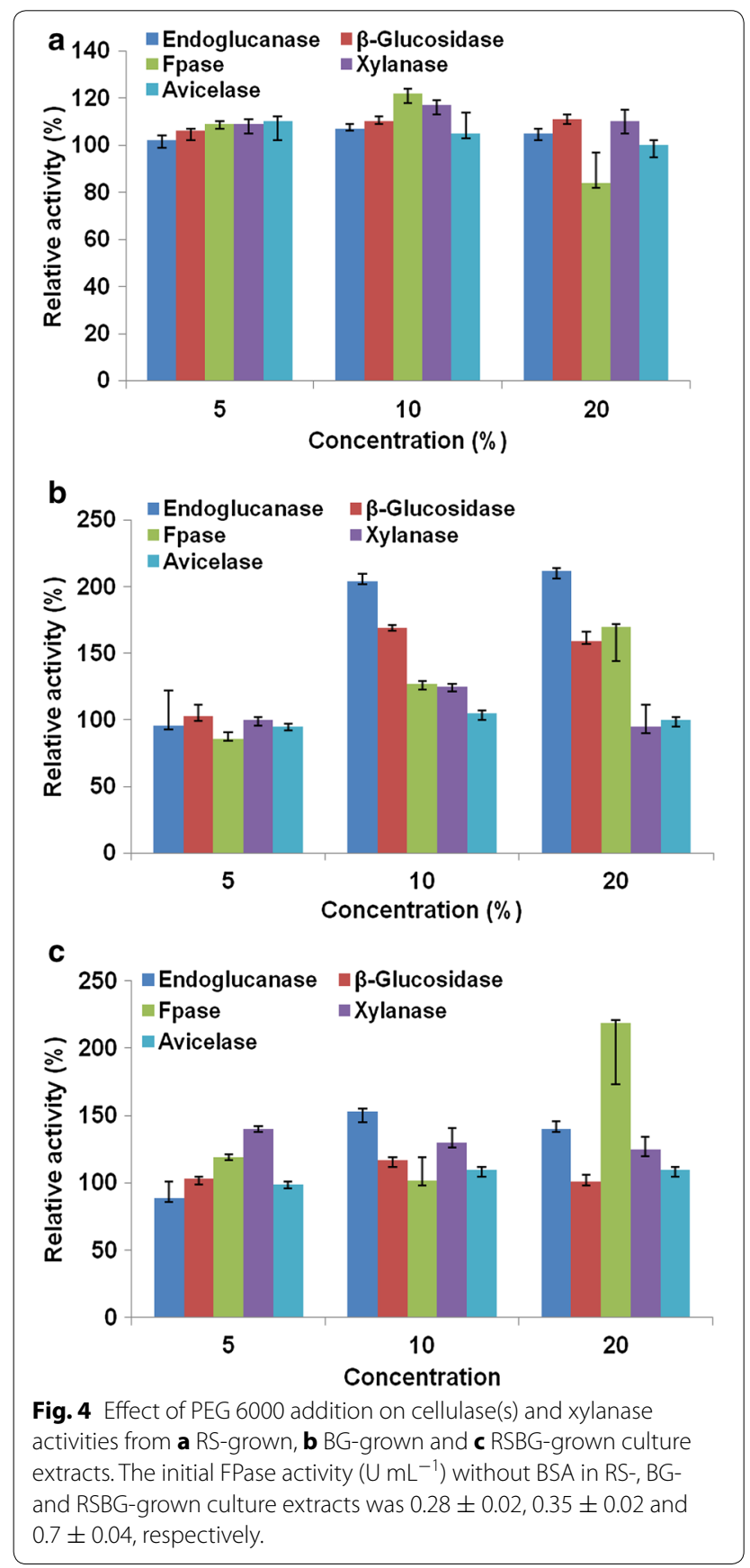

(UV1 and UV2) improved cellulase activity and extracellular protein production. However, maximum efficiency of cellulase production (2.34 FPU $\mathrm{mL}^{-1}$ ) was observed in EMS1 mutant. Enzymatic hydrolysis of mild-alkali pretreated rice straw at $10 \%$ solids loading using EMS2 mutant showed a maximum saccharification efficiency of $95 \pm 0.2 \%$ at $9 \mathrm{FPU} \mathrm{g}^{-1}$ of enzyme produced from BGgrown culture extract at $10 \%$ solids loading after $48 \mathrm{~h}$ incubation. Although the saccharification efficiencies

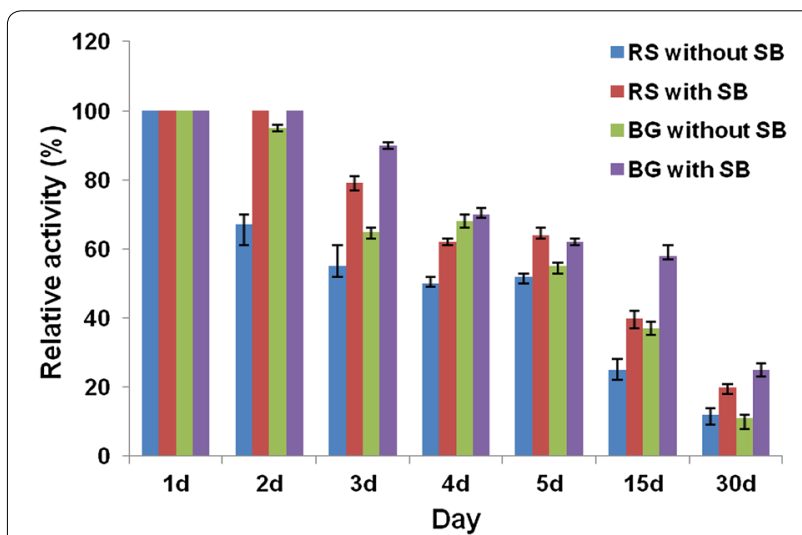

Fig. 5 Effect of sodium benzoate addition on thermal stability of crude cellulase enzyme from RS- and BG-grown culture extracts. The enzyme was incubated with $0.05 \%$ sodium benzoate at $37^{\circ} \mathrm{C}$ and residual FPase activity was measured at different time intervals. The activity corresponding to $100 \%$ residual activity at $0 \mathrm{~h}$ was $0.28 \pm 0.02 \mathrm{U} \mathrm{mL}^{-1}$ in RS- and $0.35 \pm 0.02 \mathrm{U} \mathrm{mL}^{-1}$ in BG-grown cells, respectively.

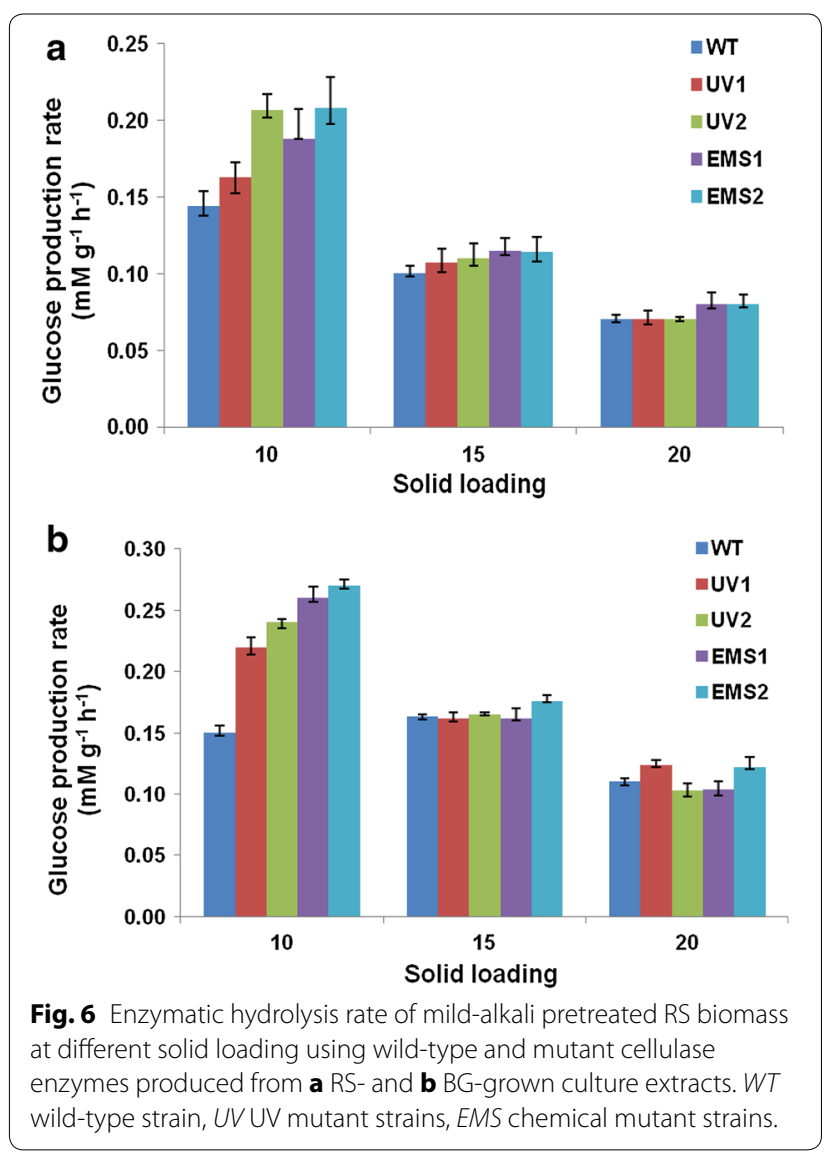

were nearly similar, due to the high cellulase activity the required amount of enzyme from mutants was almost threefold lower than the wild-type. Thus, the overall enzyme production costs may significantly reduce by 
using the EMS mutant strains in production of fermentable reducing sugars from lignocellulosic biomass residues.

\section{Additional file}

Additional file 1. In the supplementary data results from microbial growth morphology, zymographic analysis and enzyme activity profile of cellulose degrading enzymes from the wild-type and mutant strains during growth in different growth carbon substrates is shown. Besides these, effect of metabolites on cellulases production is also presented in a tabular form.

\section{Authors' contributions}

AKK designed the research and wrote the paper. BSP and DS performed the UV and chemical mutagenesis experiments. BSP performed the enzyme production and enzymatic saccharification. SPS performed biomass compositional analysis and prepared figures and tables. All authors read and approved the final manuscript.

\section{Acknowledgements}

The authors are thankful to the Director, Sardar Patel Renewable Energy Research Institute, Gujarat, India, for support of this research. The research work is financially supported by ICAR (ACRIP), Govt. of India with Grant Number WN/RES/DRET-LBT/2014/4

\section{Compliance with ethical guidelines}

\section{Competing interests}

The authors declare that they have no competing interests.

Received: 9 March 2015 Accepted: 13 July 2015

Published online: 25 July 2015

\section{References}

AOAC (1990) Official methods of analysis, 15th edn. Association of Official Analytical Chemists Inc, Arlington

Bajaj BK, Sharma M, Rao RS (2014) Agricultural residues for production of cellulase from Sporotrichum thermophile LAR5 and its application for saccharification of rice straw. J Mater Environ Sci 5:1454-1460

Bajpai P (1999) Applications of enzymes in the pulp and paper industry. Biotechnol Prog 15:147-157

Bradford MM (1976) A rapid and sensitive method for the quantitation of microgram quantities of protein utilizing the principle of protein-dye binding. Anal Biochem 72:248-254

Chand P, Aruna A, Maqsood AM, Rao LV (2005) Novel mutation method for increased cellulase production. J Appl Microbiol 98:318-323

Dashtban M, Maki M, Leung KT, Mao C, Qin W (2010) Cellulase activities in biomass conversion: measurement methods and comparison. Crit Rev Biotechnol 30:302-309

Dhawan S, Lal R, Kuhad RC (2003) Ethidium bromide stimulated hyper laccase production from bird's nest fungus Cyathus bulleri. Lett Appl Microbiol 36:64-67

El-Ghonemy DHE, Ali TH, El-Bondkly AM, Moharam MES, Talkhan FN (2014) Improvement of Aspergillus oryzae NRRL 3484 by mutagenesis and optimization of culture conditions in solid-state fermentation for the hyper-production of extracellular cellulase. Antonie Van Leeuwenhoek 106:853-864

Ghose T (1994) Measurement of cellulase activities. In: Commission on Biotechnology. IUPAC, New York, pp 1-12

Goering HK, Van Soest PJ (1970) Forage fiber analysis (apparatus, reagents, procedures and some applications). Agricultural handbook, no. 379. U.S. Agricultural Research Service

Gusakov AV (2011a) Alternatives to Trichoderma reesei in biofuel production. Cell 29:419-425

Gusakov AV (2011b) Alternatives to Trichoderma reesi in biofuel production. Trends Biotechnol 29:419-425
Harman GE, Kubicek CP (1998) Trichoderma and Gliocladium: enzymes, biological control and commercial applications, vol 2. Taylor and Francis Ltd., London, p 393

Ikehata H, Ono T (2011) The mechanisms of UV mutagenesis. J Radiat Res $52: 115-125$

Irfan M, Javed J, Syed Q (2011) UV mutagenesis of Aspergillus niger for enzyme production in submerged fermentation. Pak J Biochem Mol Biol 44:137-140

Kawamori M, Morikawa Y, Takasawa S (1986) Induction and production of cellulases by L-sorbose in Trichoderma reesi. Appl Microbiol Biotechnol 24:449-453

Kim W, Gamo Y, Sani YM, Wusiman Y, Ogawa S, Karita S et al (2006) Effect of tween 80 on hydrolytic activity and substrate accessibility of carbohyrolase (CBH I) from Trichoderma viride. Asian Aust J Anim Sci 19:684-689

Kim IJ, Lee HJ, Choi IG, Kim KH (2014) Synergetic proteins for the enhanced enzymatic hydrolysis of cellulose by cellulase. Appl Microbiol Biotechnol 98:8469-8480

Kosalkova K, Garcia-Estrada C, Barreiro C, Florez MG, Jami MS, Paniagua MA et al (2012) Casein phosphopeptides drastically increase the secretion of extacellular proteins in Aspergillus awamori. Proteomic studies reveal changes in the secretory pathway. Microb Cell Fact 11:5

Kubicek CP (1982) Beta-glucosidase excretion by Trichoderma pseudokoningii: correlation with cell wall bound beta-1,3-glucanase activities. Arch Microbiol 132:349-354

Kumar AK, Parikh BS (2015) Cellulose-degrading enzymes from Aspergillus terreus D34 and enzymatic saccharification of mild-alkali and dilute-acid pretreated lignocellulosic biomass residues. Biores Bioprocess 2:7

Laser M, Jin H, Jayawardhana K, Dale BE, Lynd LR (2009) Projected mature technology scenarios for conversion of cellulosic biomass to ethanol with co-production of thermochemical fuels, power, and/or animal feed protein. Biofuels Bioprod Biorefin 3:231-246

Lynd LR, Weimer PJ, van ZyI WH, Pretorius IS (2002) Microbial cellulase utilization: fundamentals and biotechnology. Microbiol Mol Biol Rev 66:506-577

Lynd LR, Laser MS, Bransby D, Dale BE, Davison B, Hamilton R et al (2008) How biotech can transform biofuels. Nat Biotechnol 26:169-172

Narra M, Dixit G, Divecha J, Madambar D, Shah AR (2012) Production of cellulases by solid state fermentation with Aspergillus terreus and enzymatic hydrolysis of mild alkali-treated rice straw. Biores Technol 121:355-361

Palaniyandi SA, Yang SH, Suh JW (2014) Cellulase production and saccharification of rice straw by the mutant strain Hypocrea koningii RSC1. J Basic Microbiol 54:56-65

Pandey A, Selvakumar P, Soccol CR, Nigam P (1999) Solid state fermentation for the production of industrial enzymes. Curr Sci 77:149-162

Parekh S, Vinci VA, Strobel RJ (2000) Improvement of microbial strains and fermentation processes. Appl Microbiol Biotechnol 54:287-301

Reith $\mathrm{JH}$, den Uil H, van Veen $\mathrm{H}$, de Laat WTAM, Niessen JJ, de Jong E et al (2002) Co-production of bio-ethanol, electricity and heat from biomass residues. In: proceedings of the 12th European conference on biomass for energy, industry and climate protection, 17-21 June 2002, Amsterdam, The Netherlands, pp 1118-1123

Rocha VAL, Maeda RN, Anna LMMS, Pereira N (2013) Sugarcane bagasse as feedstock for cellulase production by Trichoderma harzianum in optimized culture medium. Electron J Biotechnol. doi:10.2225/ vol16-issue5-fulltext-1

Shafique S, Rukhsana B, Sobiya S (2011) Strain improvement in Trichoderma viride through mutation for over-expression of cellulase and characterization of mutants using random amplified polymorphic DNA (RAPD). Afr J Biotechnol 10:19590-19597

Uhlig H (1998) Industrial enzymes and their applications. Wiley, New York, p 435

Van Dyk JS, Pletchke BI (2012) A review of lignocelluloses bioconversion using enzymatic hydrolysis and synergistic cooperation between enzymesfactors affecting enzymes, conversion and synergy. Biotechnol Adv 30:1458-1480

Wang H, Mochidzuki K, Kobayashi S, Hiraide H, Wang X, Cui Z (2013) Effect of bovine serum albumin (BSA) on enzymatic cellulose hydrolysis. Appl Biochem Biotechnol 170:541-551

Zong Z, Ma L, Yu L, Zhang D, Yang Z, Chen S (2015) Characterization of the interactions between polyethylene glycol and cellulase during the hydrolysis of lignocellulose. Bioenergy Res 8:270-278 